\title{
THE RELATION OF SERUM BICARBONATE CONCENTRATION TO MUSCLE COMPOSITION ${ }^{1}$
}

\author{
BY DANIEL C. DARROW, ROBERT SCHWARTZ, JOHN F. IANNUCCI, \\ AND FRANCES COVILLE
}

(From the Department of Pediatrics, Yale University School of Medicine, New Haven)

(Received for publication September 2, 1947)

Knowledge which enables one to predict the composition of intracellular as well as extracellular fluids is necessary for rational therapy of disturbances in body water and electrolyte. The present paper shows that, when the kidneys reach adjustment in the presence of a deficit of sodium or chloride or potassium, there is a predictable relationship between the concentration of bicarbonate in serum and the composition of rat muscle. At present, treatment of acidosis is guided chiefly by information that low concentration of bicarbonate in serum is explained by an absolute or relative deficiency of the sodium in extracellular fluids. Similarly, the therapy of alkalosis is based on knowledge that relative or absolute deficiency of chloride in extracellular fluids leads to high concentration of bicarbonate in serum. Although the changes in body electrolyte are not confined to extracellular electrolyte, knowledge of the quantitative aspects of the changes in intracellular fluids is just beginning to be developed. Darrow (1) has presented some of the known changes in composition of intracellular and extracellular fluids in a form which permits quantitative comparison of the changes in the two chief categories of body fluid and has discussed some of the implications of these quantitative relationships. The present paper expands and defines these relationships at biological equilibrium.

The experiments were designed to show the changes in composition of both serum and muscle which accompany certain types of deficit of potassium, in acidosis produced by deficit of sodium and in alkalosis produced by deficit of chloride. In each type of experiment, the analyses present the compositions after the kidneys have reached the adjustment which is attained in the presence of a deficit of one of the ions-sodium, chloride

1 Aided by a Grant from the Fluid Research Fund, Yale University School of Medicine, New Haven. or potassium-and are suitable to demonstrate the relation of the concentration of bicarbonate in serum to the composition of muscle.

\section{EXPERIMENTAL METHODS}

All experiments were carried out on white rats of both sexes, weighing about 300 grams. Before being used in the studies, the rats were fed Purina Fox Chow. During the experimental period three diets were used. The low potassium diet was made up as follows: Lactalbumin 18, Crisco 22, Dextrin 32, Sucrose 25, cod liver oil 1, powdered yeast 2 , bone ash $2, \mathrm{NaCl} 1 \mathrm{gram}$. In addition to the above, the normal potassium diet had 2 grams $\mathrm{KH}_{2} \mathrm{PO}_{4}$. The rats with acidosis received the same diet without bone ash or sodium chloride. The analyses of the diets are shown in Table I.

TABLE I

Composition of diets per 100 grams

\begin{tabular}{l|c|c|c|c}
\hline \hline Type of diet & $\mathrm{N}$ & $\mathrm{Cl}$ & $\mathrm{Na}$ & $\mathrm{K}$ \\
\cline { 2 - 4 } & grams & $m M$ & $m M$ & $m M$ \\
Low Cl & 2.95 & 1 & 30 & 13 \\
Low $\mathrm{Na}$ & 2.95 & 1 & 1 & 1 \\
Low K & 2.95 & 17 & 34 & 1 \\
Normal & 2.95 & 17 & 34 & 13 \\
\hline
\end{tabular}

One group of rats was adrenalectomized and kept alive for three to four days by administration of salt solution until they had recovered from the effects of the operation Other rats were subjected to similar dietary and experimental procedures except that no operation was performed. The experimental period of three weeks was then begun by giving them the synthetic diets, but the experiments on the adrenalectomized rats were terminated in two weeks, when the rats seemed unlikely to survive.

During the experimental period the rats were subdivided into groups of four, which received daily subcutaneous injections of desoxycorticosterone acetate, desoxycorticosterone acetate in conjunction with cortical extract, cortical extract or no hormones, as is indicated in Table II. The desoxycorticosterone acetate was prepared so that about $2 \mathrm{mg}$. were given in $1 \mathrm{cc}$. of a suspension of crystals. The cortical extract was Upjohn's lipo-extract which contains 40 rat growth-survival units per cubic centimeter and is equivalent per cubic centimeter to 2 
TABLE II

\begin{tabular}{|c|c|c|c|c|c|c|c|c|c|c|c|c|c|c|c|c|c|c|c|c|}
\hline \multirow{2}{*}{$\begin{array}{l}\text { Group } \\
\text { No. }\end{array}$} & \multirow{2}{*}{$\begin{array}{l}\text { Rat } \\
\text { No. }\end{array}$} & \multirow{2}{*}{$\begin{array}{l}\text { Pe- } \\
\text { riod }\end{array}$} & \multirow{2}{*}{ Diet* } & \multirow{2}{*}{$\begin{array}{c}\text { Injec- } \\
\text { tion }\end{array}$} & \multirow{2}{*}{$\begin{array}{c}\text { Adre- } \\
\text { nal- } \\
\text { ectomy }\end{array}$} & \multicolumn{8}{|c|}{ Muscle composition per 100 grams fat-free solids } & \multicolumn{7}{|c|}{ Serum concentrations per liter } \\
\hline & & & & & & Fat & $\mathrm{H}_{2} \mathrm{O}$ & $\mathbf{N}$ & $\mathrm{Cl}$ & $\mathrm{Na}$ & $\mathbf{K}$ & $\mathbf{P}$ & $(\mathrm{Na})_{\mathbf{i}}$ & $\mathrm{H}_{8} \mathrm{O}$ & $\mathrm{HCO}_{2}$ & $\mathrm{Cl}$ & $\mathrm{Na}$ & $\mathbf{k}$ & $\mathrm{pH}$ & $\mathrm{PCO}_{2}$ \\
\hline 1 & 13 & days & $\mathrm{N}$ & 0 & 0 & grams & $\begin{array}{c}\text { grams } \\
340 \\
6\end{array}$ & \begin{tabular}{|r} 
grams \\
15.3 \\
0.3
\end{tabular} & \begin{tabular}{|c|}
$m M$ \\
7.1 \\
0.5
\end{tabular} & \begin{tabular}{|c|}
$m M$ \\
10.0 \\
0.6
\end{tabular} & $\begin{array}{c}m M \\
48.9 \\
0.6\end{array}$ & \begin{tabular}{|c|}
$m M$ \\
32.4 \\
1.5
\end{tabular} & $\begin{array}{c}m M \\
3.1\end{array}$ & $\begin{array}{r}\text { grams } \\
933 \\
5\end{array}$ & $\begin{array}{r}m M \\
20.9 \\
2.4\end{array}$ & \begin{tabular}{|r|}
$m M$ \\
102.6 \\
0.6
\end{tabular} & \begin{tabular}{|c|}
$m M$ \\
143 \\
2.9
\end{tabular} & $\begin{array}{l}m M \\
5.4 \\
0.3\end{array}$ & \begin{tabular}{|l|}
7.28 \\
0.03
\end{tabular} & $\begin{array}{c}\mathrm{mm}_{\boldsymbol{H}} . \\
44 \\
44\end{array}$ \\
\hline 2 & 3 & 21 & $\mathrm{~N}$ & $\mathrm{CE}$ & 0 & $\begin{array}{l}3.0 \\
0.8\end{array}$ & $\begin{array}{r}343 \\
3\end{array}$ & $\begin{array}{r}14.2 \\
0.2\end{array}$ & \begin{tabular}{l|}
5.7 \\
0.2
\end{tabular} & $\begin{array}{l}8.8 \\
0.4\end{array}$ & $\begin{array}{r}46.4 \\
0.5\end{array}$ & $\begin{array}{r}31.7 \\
0.2\end{array}$ & $\begin{array}{l}3.4 \\
0.4\end{array}$ & $\begin{array}{r}935 \\
8\end{array}$ & $\begin{array}{r}22.0 \\
1.5\end{array}$ & $\begin{array}{r}108.8 \\
2.6\end{array}$ & $\begin{array}{c}138 \\
2.7\end{array}$ & $\begin{array}{l}7.2 \\
0.6\end{array}$ & $\begin{array}{l}7.23 \\
0.03\end{array}$ & 48 \\
\hline 3 & 4 & 21 & $\mathrm{~N}$ & D & 0 & $\begin{array}{l}4.1 \\
1.0\end{array}$ & $\begin{array}{r}325 \\
3\end{array}$ & $\begin{array}{r}14.0 \\
0.3\end{array}$ & \begin{tabular}{|l|}
5.4 \\
0.2
\end{tabular} & $\begin{array}{r}14.9 \\
0.8\end{array}$ & $\begin{array}{r}36.3 \\
1.7\end{array}$ & $\begin{array}{r}30.4 \\
0.8\end{array}$ & $\begin{array}{l}8.7 \\
0.7\end{array}$ & $\begin{array}{r}930 \\
2\end{array}$ & $\begin{array}{r}30.2 \\
2.0\end{array}$ & $\begin{array}{r}92.1 \\
4.5\end{array}$ & \begin{tabular}{|c|}
144 \\
4.4
\end{tabular} & $\begin{array}{l}7.8 \\
1.3\end{array}$ & & \\
\hline 4 & 4 & 21 & $\mathrm{~N}$ & DCE & 0 & $\begin{array}{l}3.0 \\
1.1\end{array}$ & $\begin{array}{r}326 \\
8\end{array}$ & $\begin{array}{r}13.2 \\
0.4\end{array}$ & $\begin{array}{l}5.7 \\
0.3\end{array} \mid$ & $\begin{array}{r}16.6 \\
1.4\end{array}$ & $\begin{array}{r}35.5 \\
1.4\end{array}$ & $\begin{array}{r}30.1 \\
0.9\end{array}$ & $\begin{array}{l}9.8 \\
1.3\end{array}$ & $\begin{array}{r}932 \\
4\end{array}$ & $\begin{array}{r}30.0 \\
2.4\end{array}$ & \begin{tabular}{|r|}
97.4 \\
4.7
\end{tabular} & $\begin{array}{r}147 \\
1\end{array}$ & $\begin{array}{l}5.0 \\
0.2\end{array}$ & & \\
\hline 5 & 2 & 21 & LK & 0 & 0 & $\begin{array}{r}11.8 \\
1.3\end{array}$ & $\begin{array}{r}314 \\
24\end{array}$ & $\begin{array}{r}15.3 \\
0.1\end{array}$ & \begin{tabular}{|l|}
5.6 \\
0.5
\end{tabular} & $\begin{array}{l}8.5 \\
0.2\end{array}$ & $\begin{array}{r}39.9 \\
0.6\end{array}$ & $\begin{array}{r}31.5 \\
0.5\end{array}$ & \begin{tabular}{l|}
6.7 \\
0.8
\end{tabular} & $\begin{array}{r}928 \\
3\end{array}$ & \begin{tabular}{|r|}
30.3 \\
1.0
\end{tabular} & $\begin{array}{r}94.0 \\
5.0\end{array}$ & $\begin{array}{r}147.5 \\
1.5\end{array}$ & $\begin{array}{l}5.1 \\
0.03\end{array}$ & & \\
\hline 6 & 4 & 21 & LK & $\mathrm{CE}$ & 0 & $\begin{array}{l}8.1 \\
1.0\end{array}$ & $\begin{array}{r}327 \\
5\end{array}$ & $\begin{array}{r}15.0 \\
0.3\end{array}$ & \begin{tabular}{l|}
5.5 \\
0.7
\end{tabular} & $\begin{array}{r}11.4 \\
0.4\end{array}$ & $\begin{array}{r}43.6 \\
0.5\end{array}$ & $\begin{array}{r}28.0 \\
1.8\end{array}$ & $\begin{array}{l}5.9 \\
0.9\end{array}$ & $\begin{array}{r}943 \\
2\end{array}$ & $\begin{array}{r}26.3 \\
1.4\end{array}$ & $\begin{array}{r}100.8 \\
1.2\end{array}$ & $\begin{array}{c}138 \\
2.5\end{array}$ & $\begin{array}{l}6.6 \\
0.3\end{array}$ & \begin{tabular}{|l|}
7.43 \\
0.02
\end{tabular} & 37 \\
\hline 7 & 4 & 21 & LK & D & 0 & $\begin{array}{l}7.9 \\
1.0\end{array}$ & $\begin{array}{r}326 \\
8\end{array}$ & $\begin{array}{r}15.0 \\
0.2\end{array}$ & \begin{tabular}{|l|}
5.5 \\
0.3
\end{tabular} & \begin{tabular}{|r|}
19.8 \\
1.0
\end{tabular} & $\begin{array}{r}34.0 \\
1.1\end{array}$ & $\begin{array}{r}26.5 \\
0.9\end{array}$ & $\begin{array}{r}13.2 \\
1.6\end{array}$ & $\begin{array}{r}936 \\
8\end{array}$ & $\begin{array}{r}38.1 \\
4.0\end{array}$ & $\begin{array}{r}85.3 \\
2.4\end{array}$ & $\begin{array}{c}141 \\
1.7\end{array}$ & $\begin{array}{l}5.8 \\
1.2\end{array}$ & $\begin{array}{l}7.4 \\
0.0\end{array}$ & 52 \\
\hline 8 & 4 & 21 & LK & DCE & 0 & $\begin{array}{r}11.5 \\
0.6\end{array}$ & $\begin{array}{r}334 \\
9\end{array}$ & $\begin{array}{r}15.6 \\
0.4\end{array}$ & \begin{tabular}{|l|}
5.6 \\
0.3
\end{tabular} & $\begin{array}{r}18.5 \\
1.2\end{array}$ & $\begin{array}{r}34.3 \\
1.1\end{array}$ & $\begin{array}{r}31.3 \\
0.5\end{array}$ & $\begin{array}{r}13.1 \\
0.6\end{array}$ & $\begin{array}{r}939 \\
8\end{array}$ & $\begin{array}{r}40.0 \\
2.5\end{array}$ & $\begin{array}{r}86.0 \\
4.0\end{array}$ & $\begin{array}{r}143 \\
6\end{array}$ & $\begin{array}{l}5.1 \\
0.3\end{array}$ & $\begin{array}{l}7.4 \\
0.0\end{array}$ & 59 \\
\hline 9 & 3 & 14 & LK & 0 & + & 11.8 & 350 & 16.6 & 6.6 & 10.9 & 46.9 & 32.9 & 4.1 & $\begin{array}{r}944 \\
6\end{array}$ & \begin{tabular}{|r|}
22.1 \\
1.0
\end{tabular} & \begin{tabular}{|r|}
99.9 \\
5.9
\end{tabular} & $\begin{array}{c}134 \\
4.8\end{array}$ & $\begin{array}{l}7.4 \\
0.5\end{array}$ & $\begin{array}{l}7.3 \\
0.0\end{array}$ & 44 \\
\hline 10 & 3 & 14 & LK & CE & + & $\begin{array}{l}6.5 \\
1.9\end{array}$ & $\begin{array}{r}335 \\
8\end{array}$ & $\begin{array}{r}15.6 \\
0.8\end{array}$ & \begin{tabular}{|l|}
5.7 \\
0.3
\end{tabular} & \begin{tabular}{|r|}
15.9 \\
1.0
\end{tabular} & $\begin{array}{r}33.5 \\
3.3\end{array}$ & $\begin{array}{r}26.6 \\
0.5\end{array}$ & $\begin{array}{l}9.4 \\
0.9\end{array}$ & $\begin{array}{r}946 \\
3\end{array}$ & $\begin{array}{r}31.6 \\
4.0\end{array}$ & \begin{tabular}{|r|}
96.4 \\
3.9 \\
\end{tabular} & $\begin{array}{c}145 \\
2.6\end{array}$ & $\begin{array}{l}4.4 \\
1.9\end{array}$ & $\begin{array}{l}7.34 \\
0.02\end{array}$ & 60 \\
\hline 11 & 3 & 14 & LK & D & + & 11.3 & $\begin{array}{r}331 \\
4\end{array}$ & $\begin{array}{r}15.7 \\
0.4\end{array}$ & $\begin{array}{l}4.5 \\
0.9\end{array}$ & $\begin{array}{r}20.8 \\
2.1\end{array}$ & $\begin{array}{r}34.4 \\
2.3\end{array}$ & $\begin{array}{r}30.4 \\
0.7\end{array}$ & $\begin{array}{r}15.7 \\
2.6\end{array}$ & $\begin{array}{r}943 \\
2\end{array}$ & $\begin{array}{r}39.2 \\
1.2\end{array}$ & $\begin{array}{r}88.3 \\
5.5\end{array}$ & \begin{tabular}{|c|}
139 \\
2.9
\end{tabular} & $\begin{array}{l}6.1 \\
1.5\end{array}$ & \begin{tabular}{|l|}
7.40 \\
0.08
\end{tabular} & 60 \\
\hline 12 & 3 & 14 & LK & DCE & + & $\begin{array}{l}6.8 \\
1.3\end{array}$ & $\begin{array}{r}338 \\
4\end{array}$ & $\begin{array}{r}15.7 \\
0.3\end{array}$ & $\begin{array}{l}6.0 \\
0.6\end{array}$ & $\begin{array}{r}20.9 \\
2.6\end{array}$ & $\begin{array}{r}33.5 \\
1.4\end{array}$ & $\begin{array}{r}30.3 \\
1.0\end{array} \mid$ & $\begin{array}{r}13.8 \\
1.0\end{array}$ & $\begin{array}{r}943 \\
3\end{array}$ & $\begin{array}{r}38.2 \\
2.2\end{array}$ & \begin{tabular}{|r|}
93.0 \\
3.2 \\
\end{tabular} & $\begin{array}{c}143 \\
1.4\end{array}$ & $\begin{array}{l}6.5 \\
2.5\end{array}$ & \begin{tabular}{|l|}
7.43 \\
0.03
\end{tabular} & 62 \\
\hline 13 & 5 & 2 & $\mathrm{LNa}$ & 0 & 0 & & $\begin{array}{r}341 \\
5\end{array}$ & $\begin{array}{r}14.1 \\
0.1\end{array}$ & $\begin{array}{l}4.9 \\
0.2\end{array}$ & $\begin{array}{l}6.6 \\
0.3\end{array}$ & $\begin{array}{r}49.5 \\
1.0\end{array}$ & $\begin{array}{r}33.7 \\
0.4\end{array}$ & $\begin{array}{l}1.3 \\
0.6\end{array}$ & $\begin{array}{r}910 \\
2\end{array}$ & $\begin{array}{r}14.6 \\
2.3\end{array}$ & $\begin{array}{r}93.6 \\
2.4\end{array}$ & $\begin{array}{r}138.8 \\
2.5\end{array}$ & $\begin{array}{l}6.8 \\
0.5\end{array}$ & & \\
\hline 14 & 4 & 6 & $\mathrm{LCl}$ & 0 & 0 & $\begin{array}{r}11.0 \\
1.0\end{array}$ & $\begin{array}{r}337 \\
6\end{array}$ & $\begin{array}{r}14.7 \\
0.1\end{array}$ & $\begin{array}{l}5.0 \\
0.4\end{array}$ & $\begin{array}{r}15.2 \\
0.6\end{array}$ & $\begin{array}{r}38.2 \\
2.0\end{array}$ & $\begin{array}{r}31.7 \\
0.8\end{array}$ & $\begin{array}{l}9.5 \\
0.6\end{array}$ & $\begin{array}{r}935 \\
1\end{array}$ & \begin{tabular}{|r|}
32.8 \\
4.0
\end{tabular} & $\begin{array}{r}79.5 \\
2.1\end{array}$ & $\begin{array}{r}142.7 \\
0.5\end{array}$ & $\begin{array}{l}4.3 \\
0.6\end{array}$ & & \\
\hline
\end{tabular}

mg. compound $\mathrm{E}$ or $4 \mathrm{mg}$. of corticosterone. The daily dose of extract was 0.1 cc.

Acidosis was produced in rats by injecting into the peritoneal cavity a 5 per cent solution of glucose containing about $60 \mathrm{mM}$ of $\mathrm{NH}_{4} \mathrm{Cl}$ per liter. About 100 cc. per kilogram of rat were injected and the fluid remaining after four hours was removed through a small abdominal incision. The rats were kept on the synthetic diet without added bone ash or sodium chloride for two days. This procedure removed about $10 \mathrm{mM}$ of sodium and 5 $\mathrm{mM}$ of chloride per kilogram of rat and at the end of the experiments the serum concentration of bicarbonate varied from 11 to $18 \mathrm{mM}$ per liter. The details of the acidosis experiments are recorded in the thesis of Robert Schwartz (2).

The alkalosis experiments were reported previously as
Group 4 (3) and are represented in the present paper as Group 14. In these experiments a glucose solution containing $150 \mathrm{mM}$ of $\mathrm{NaHCO}_{3}$ per liter was injected into the peritoneal cavity and withdrawn after four hours. The rats were permitted to survive on a diet deficient only in chloride for six days.

At the end of the experimental period, the rats were anesthetized with ether, and as much blood as possible was withdrawn from the abdominal aorta by inserting a needle attached to a syringe containing mineral oil. The rats were then immediately killed by excising the heart. The muscles of the legs were removed, freed from excessive amounts of fat and nerves, and analyzed by the methods used previously in this laboratory (4). The estimation of $\mathrm{pH}$ was done with a glass electrode at $38^{\circ} \mathrm{C}$. The determinations of $\mathrm{pH}$ were carried out on 
serum, when sufficient blood was obtained. Unfortunately, the $\mathrm{pH}$ was not estimated in the later experiments, because the apparatus was out of order.

Four rats were started in each experimental group, but in some groups one rat died or blood was not obtained in sufficient quantity. Some groups are, therefore, represented by analyses of only two or three animals. Table II shows the average \pm the standard deviation. Attention is directed to the fact that the muscle analyses are calculated per 100 grams of fat-free solids. This method of presentation (3) was used because the fat-free solids are chiefly intracellular and hence the values for intracellular constituents are practically unaffected by changes in the volume of extracellular water. Furthermore, the data show no close relation of the volume of intracellular water or the concentration of intracellular electrolyte to the concentration of extracellular sodium. Hence the changes in intracellular electrolyte are most simply represented in terms of fat-free solids.

The intracellular sodium was calculated as follows:

$$
\begin{gathered}
\frac{(\mathrm{Cl})-1}{[\mathrm{Cl}]_{e}}=\left(\mathrm{H}_{2} \mathrm{O}\right)_{\bullet} \\
(\mathrm{Na})-\left(\mathrm{H}_{2} \mathrm{O}\right)_{e}[\mathrm{Na}]_{e}=(\mathrm{Na})_{i}
\end{gathered}
$$

in which $(\mathrm{Cl})$ and $(\mathrm{Na})$ are total tissue chloride and sodium per 100 grams of fat-free solids; $\left(\mathrm{H}_{2} \mathrm{O}\right)$. is the extracellular water per 100 grams of fat-free solids; $(\mathrm{Na})_{1}$ is the intracellular sodium per 100 grams of fatfree solids. $[\mathrm{Cl}]$. and $[\mathrm{Na}]$. are the concentration of chloride and sodium in an ultrafiltrate of serum calculated from the serum concentrations and the serum water and an average Donnan factor of 0.96 . In the first equation the 1 represents an average correction for nonextracellular chloride (4).

\section{RESULTS}

As shown in Group 1, the usual value for the muscle potassium of normal rats on a normal diet is $49 \mathrm{mM}$ per 100 grams of fat-free solids. The standard deviation is somewhat deceiving, since Miller and Darrow (5) found that essentially normal rats may show values as low as $44 \mathrm{mM}$, but potassium in muscle probably does not go below this figure in normal rats. In adrenalectomized rats muscle potassium is 52 , when the rats are fed a diet of the usual salt content (6). Therefore the two different sets of values for normal and adrenalectomized rats should be used in determining changes in muscle composition brought about by either the diet or the injections of cortical extract or desoxycorticosterone acetate.

The results in unoperated rats fed the normal diet are shown in Groups 1 through 4. The injection of cortical extract (Group 2) did not change the muscle composition unmistakably though the concentration of chloride in serum is a little high (109 $\mathrm{mM}$ per liter). However, the injection of desoxycorticosterone acetate alone or in conjunction with cortical extract (Groups 3 and 4) lowered the muscle potassium to $36 \mathrm{mM}$ per 100 grams of fat-free solids and increased the intracellular sodium to about $9 \mathrm{mM}$ per 100 grams of fat-free solids. The decrease in muscle potassium and the increase in intracellular sodium following injections of desoxycorticosterone acetate have been previously demonstrated $(5,7$ to 9). The present experiments show that the muscle changes are accompanied by an increase in concentration of bicarbonate in serum to $30 \mathrm{mM}$ per liter. The rise in serum bicarbonate was missed in the previous work since this determination was omitted. However, the previous work showed a decrease in serum chloride and normal or high serum sodium. These findings almost certainly indicate that high concentration of bicarbonate in serum could have been demonstrated.

The results on unoperated rats fed a diet low in potassium are shown in Groups 5 through 8 . Group 5 shows that diets low in potassium decrease muscle potassium to 40 and increase intracellular sodium to $6.7 \mathrm{mM}$ per 100 grams of fat-free solids. Accompanying the changes in muscle, the concentration of bicarbonate in serum increased to $30 \mathrm{mM}$ per liter and the concentration of chloride in serum decreased to $94 \mathrm{mM}$ per liter. Though less marked, these changes are similar to those produced by injections of desoxycorticosterone acetate in rats fed a normal diet. The injection of cortical extract in rats fed a diet low in potassium (Group 6) was. not followed by as great a lowering of muscle potassium or as great a rise in serum bicarbonate. However, the in. jection of desoxycorticosterone acetate alone or in conjunction with cortical extract (Groups 7 and 8) decreased muscle potassium to 34 and increased intracellular sodium to $13 \mathrm{mM}$ per 100 grams of fat-free solids. The most striking change in these groups is the increase in serum bicarbonate to about $39 \mathrm{mM}$ per liter and the reduction of serum chloride to about $85 \mathrm{mM}$ per liter.

Groups 9 through 12 show the results in adrenalectomized rats on a diet low in potassium. If one recalls that a diet of normal potassium con- 
tent is likely to produce high muscle potassium and may lead to early death, the diet low in potassium (Group 9) did produce an effect in preserving muscle composition at approximately normal concentrations. However, serum sodium is definitely low despite normal bicarbonate and chloride. The adrenalectomized rats receiving cortical extract (Group 10) were more vigorous than the untreated ones of Group 9. It is, therefore, interesting to observe that the muscle composition is more abnormal in Group 10. The potassium is as much reduced as in normal rats on a normal diet receiving desoxycorticosterone acetate (Groups 3 and 4 ) or the normal rats on a diet low in potassium receiving desoxycorticosterone acetate (Groups 7 and 8). Accompanying the change in muscle composition, serum bicarbonate is 32 , serum chloride 96 , and serum sodium $145 \mathrm{mM}$ per liter. While the cortical extract did not produce completely normal functions in the adrenalectomized rats, the changes demonstrated are of the same type as was seen in normal rats on a diet low in potassium. For this reason, the dose of cortical extract is adequate to produce an effect in animals producing no cortical hormone, i.e., the dose is adequate to produce an effect in adrenalectomized rats. The injections of desoxycorticosterone acetate alone or in conjunction with cortical extract (Groups 11 and 12) probably produce essentially the same effect in adrenalectomized rats as the same injections in normal rats (Groups 3, 4, 7 and 8 ). The higher value for intracellular sodium in Group 11 is dependent on the one aberrant intracellular sodium mentioned later. The lowering of muscle potassium and increase in serum bicarbonate are striking in these two groups.

The rats suffering from acidosis (Group 13) show changes in muscle composition which fit in with the above findings. Lowering of serum bicarbonate decreased the intracellular sodium while muscle potassium remained normal or slightly high.

The rats suffering from alkalosis produced by deficit of chloride (Group 14) resemble the rats on a diet deficient in potassium or receiving desoxycorticosterone acetate. Muscle potassium is 38 and the intracellular sodium is $9.5 \mathrm{mM}$ per 100 grams of fat-free solids. The serum bicarbonate and chloride were 33 and $80 \mathrm{mM}$ per liter.
The data have been analyzed for relationships between the concentration of serum sodium and the total intracellular water per 100 grams of fatfree solids and the apparent concentration of sodium plus potassium in intracellular water. Although there are striking variations in these two values, no correlation is found with the concentration of sodium in serum. In acute experiments a decrease in concentration of sodium in serum leads to an increase in intracellular water and a decrease in the concentration of univalent cations in intracellular water (4). In the present experiments in which the rats have reached a biological equilibrium no such relationship is found. The lack of correlation between the concentration of sodium in serum and the concentration of univalent cations in intracellular water is supported by findings in patients and experimental animals (10).

There are striking decreases in muscle phosphorus in Groups 6, 7 and 10, and somewhat smaller decreases in some other groups. These changes are not associated consistently with any type of change in the serum or other constituents of the muscle. Since the values for muscle phosphorus include all muscle phosphorus, studies of

TABLE III

Statistical data on relationships of serum and muscle compositions

\begin{tabular}{|c|c|c|c|}
\hline \multicolumn{2}{|c|}{$\begin{array}{c}\text { Average and standard } \\
\text { deviation }\end{array}$} & \multicolumn{2}{|c|}{ Correlation coefficients } \\
\hline $\begin{array}{l}(\mathrm{K}) \mathrm{mM} \\
(\mathrm{Na})_{\mathrm{i}} \mathrm{mM} \\
(\mathrm{HCO}), \mathrm{mM} \\
(\mathrm{Cl})_{0} \mathrm{mM}\end{array}$ & $\begin{array}{r}40.22 \pm 6.21 \\
7.91 \pm 4.48 \\
28.65 \pm 8.04 \\
94.39 \pm 8.10\end{array}$ & 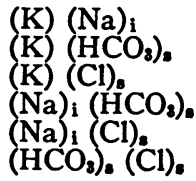 & $\begin{array}{r}-0.90 \\
-0.90 \\
0.47 \\
0.94 \\
-0.57 \\
-0.59\end{array}$ \\
\hline
\end{tabular}

$(\mathrm{K})$ is total muscle potassium and $(\mathrm{Na})_{i}$ is intracellular muscle sodium per 100 grams of fat-free solids. ( $\mathrm{HCO}_{3}$ ), and $(\mathrm{Cl})$, are the respective concentrations per liter of serum.

Regression equations calculated from Table III

$$
\begin{aligned}
& (\mathrm{K})=50.1-1.25(\mathrm{Na})_{\mathrm{i}} \pm 2.7 \\
& (\mathrm{Na})_{\mathrm{i}}=34.0-0.65(\mathrm{~K}) \pm 1.9 \\
& (\mathrm{~K})=60.1-0.696\left(\mathrm{HCO}_{3}\right)_{ \pm} \pm 2.7 \\
& \left(\mathrm{HCO}_{3}\right)_{\mathrm{a}}=75.6-1.165(\mathrm{~K}) \quad \pm 3.5 \\
& (\mathrm{~K})=0.36(\mathrm{Cl})_{\bullet}+6.0 \pm 5.5 \\
& \text { (CI), }=0.61(\mathrm{~K})+68.7 \pm 7.1 \\
& (\mathrm{Na})_{\mathrm{i}}=0.52\left(\mathrm{HCO}_{3}\right)_{9}-7.1 \pm 1.5 \\
& \left.\left(\mathrm{HCO}_{3}\right)_{\mathrm{a}}=1.69(\mathrm{Na})_{1}\right)_{1}+15.3 \pm 2.6 \\
& (\mathrm{Na})_{\mathrm{i}}=37.7-0.32(\mathrm{Cl})_{2} \pm 3.6 \\
& (\mathrm{Cl})_{\mathrm{a}}=102.5-1.026(\mathrm{Na})_{\mathrm{i}} \pm 6.6 \\
& \begin{array}{l}
(\mathrm{Cl})_{3}=111.4-0.59\left(\mathrm{HCO}_{8}\right)_{8} \pm 3.4 \\
\left(\mathrm{HCO}_{3}\right)_{4}=93.9-0.59(\mathrm{Cl})_{9} \pm 3.4
\end{array}
\end{aligned}
$$




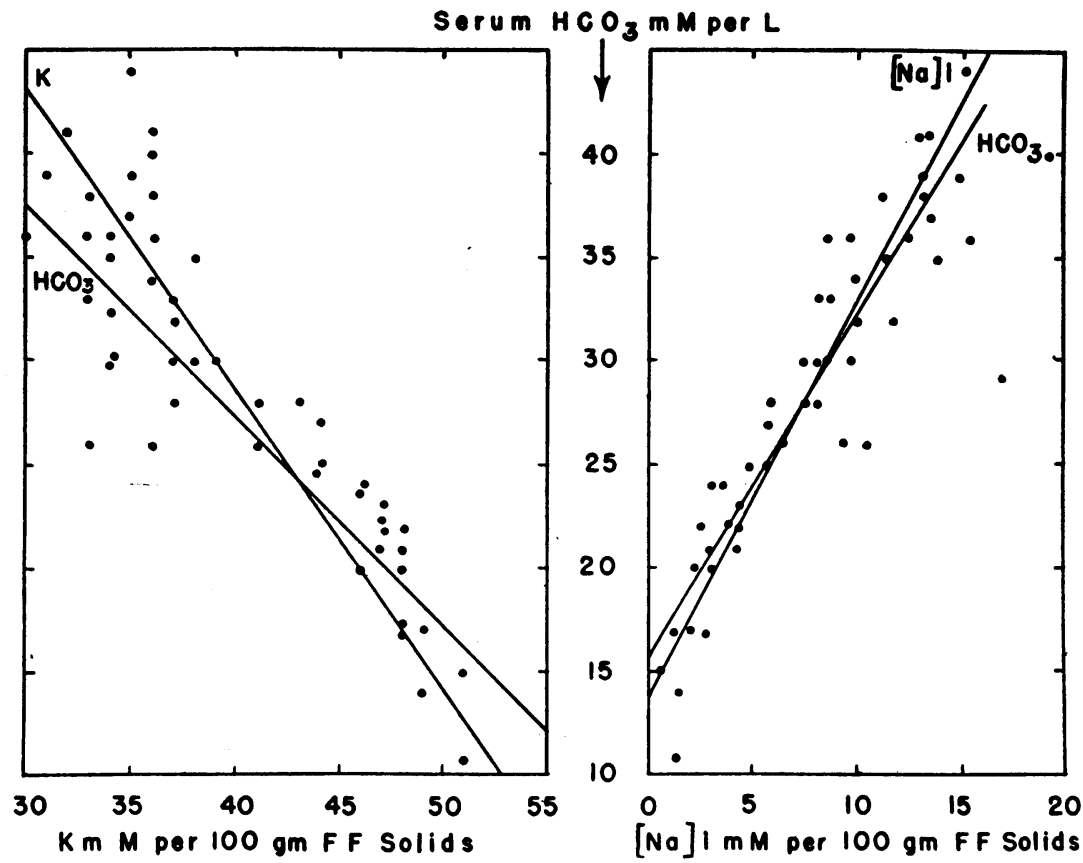

Fig. 1. Relation of the Concentration of Bicarbonate in Serum to the Total Potassium and Intracellular Sodium of Rat Muscle per 100 Grams of Fat-Free Solids

the various types of compounds might throw light on the decreases in total phosphorus.

Table III shows the correlation coefficients of certain values of the serum and muscle. The chief interest is the interrelationship between serum bicarbonate, muscle potassium ${ }^{2}$ and intracellular sodium which are defined in the regression equations and illustrated in Figures 1 and 2. The correlations between serum chloride and serum bicarbonate, serum chloride and muscle potassium, and serum chloride and intracellular sodium are definite, but not as precise as the correlations between serum bicarbonate and intracellular cations. For this reason the fundamental correlation of intracellular cations and serum concentrations is regarded as dependent on serum bicarbonate rather than serum chloride. The relation of muscle potassium and intracellular sodium to serum chloride is secondary relationship dependent on the inverse relationship between serum chloride and serum bicarbonate.

\footnotetext{
2 It is realized that equilibrium would be theoretically more accurately stated in terms of intracellular potassium. Since the correction for extracellular potassium is small and approximately the same in all groups, the total muscle potassium was used.
}

As is indicated by the correlation coefficients, there are few aberrant values. In the largest deviation (one of the values in Group 11), the intracellular sodium is $19 \mathrm{~mm}$. per 100 grams of fat-free solids, when the serum bicarbonate would predict a value of 14 . In this case muscle potassium is essentially that predicted by serum bicarbonate. Either the determination of muscle sodium or chloride is erroneous in this case or occasional values deviate considerably from the predicted value. With this exception, the concentration of serum bicarbonate predicts the composition of muscle with respect to potassium and intracellular sodium with surprising accuracy in this series of animals. The values for the rats with acidosis fall along the lines. More values in the group with acidosis might bring out a resistance to lowering of intracellular sodium below $1 \mathrm{~mm}$. per 100 grams of fat-free solids. Previous work has indicated that muscle potassium seldom rises over $50 \mathrm{~mm}$. per 100 grams of fat-free solids except when serum potassium is increased $(5,7)$. For this reason acidosis may not lead to great increase in muscle potassium unless serum potassium rises. Doubtless other variables are involved in the relationship between intracellular 


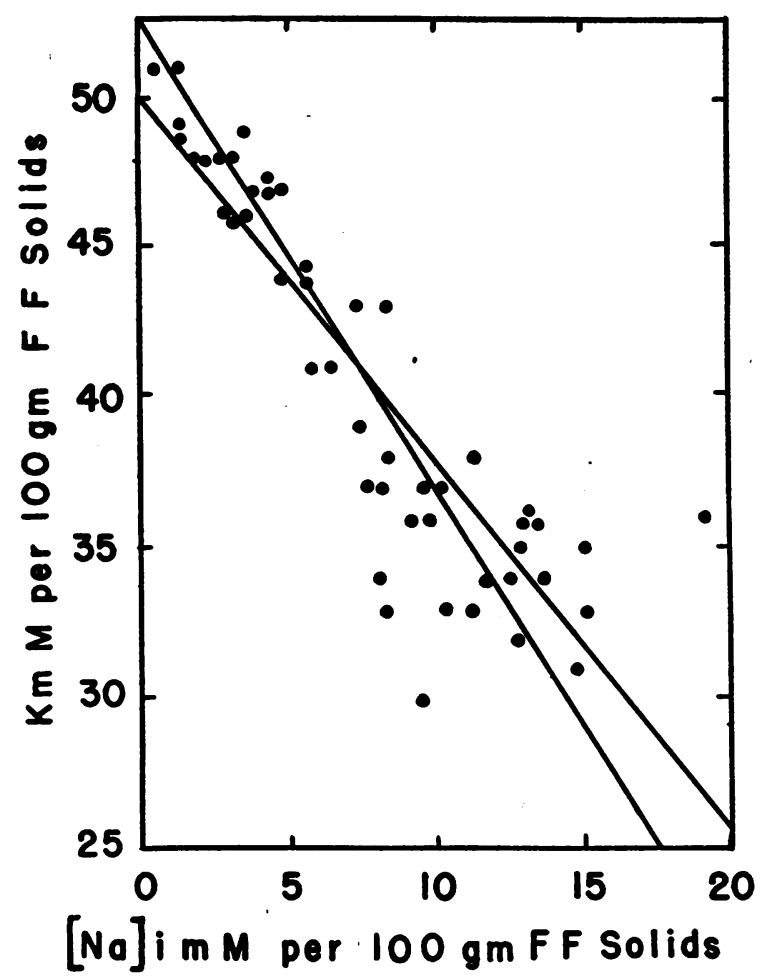

Fig. 2. Relation of Total Potassium to Intracellular Sodium in Rat Muscle per 100 Grams of Fat-Free Solids

composition and serum concentrations, but the concentration of bicarbonate in serum is one of the most important factors.

Normal serum bicarbonate is $21 \mathrm{~mm}$. per liter and the $\mathrm{pH}$ is 7.28 when the blood is taken as in these experiments. Owing to the fact that the rats were anesthetized and bled from the abdominal aorta after opening the abdomen, the $\mathrm{pH}$ and carbon dioxide tensions are probably unreliable as measurements of undisturbed animals. It will be noticed that the carbon dioxide pressures are high in the cases with high concentration of bicarbonate in serum. Since the carbon dioxide pressure is relatively normal in the rats with normal concentrations of bicarbonate in serum, the increase in carbon dioxide pressure in the rats with high serum bicarbonate is evidence of some respiratory compensation, but not sufficient to produce the same $\mathrm{pH}$ as was obtained in the normal group.

Sections of the heart were examined for the lesions associated with low muscle potassium. There was no striking difference in the extent of the lesions except as associated with loss of muscle potassium. In this respect the normal and adrenalectomized rats are alike. These observations were made because heart symptoms have seemed unduly prominent in cases of Addison's disease treated with desoxycorticosterone acetate. It was felt that cortical extract might provide some protection from the lesions produced by desoxycorticosterone acetate, but the histological sections do not support this supposition. Since the intake of sodium chloride was about the same in these experiments, this finding is in agreement with recent work which indicates that renal and heart lesions require the combined effect of sodium chloride and desoxycorticosterone acetate (11).

\section{DISCUSSION}

The experimental demonstrations of the correlation between the serum bicarbonate, muscle potassium and intracellular sodium have been obtained by four methods of producing changes either in the serum or muscle. First the diets low in potassium produce loss of potassium from the cells owing to inability of the kidneys to prevent loss of potassium when the diets contain little potassium and considerable sodium chloride. The importance of sodium chloride was brought out in unpublished observations on rats fed a diet similar to the low potassium diet of the present experiments except that no sodium chloride was added. This diet did not produce striking change in muscle composition or serum bicarbonate. Second, desoxycorticosterone acetate augments the excretion of potassium so that deficit of muscle potassium develops on normal diets. Desoxycorticosterone acetate also aggravates the effect of diets low in potassium. Third, the experiments previously published (3) produced alkalosis by injecting sodium bicarbonate in 5 per cent glucose into the peritoneal cavity. If a diet deficient in chloride was given for six days after removing the fluid equilibrated in the peritoneal cavity, the muscles lost potassium and gained intracellular sodium, and the concentration of bicarbonate in serum remained high. Fourth, acidosis produced by deficit of sodium induced the opposite effect on muscle. Thus, it seems clear that there is a biological equilibrium or biological steady state in which these three variables bear predictable relationships to each other, when renal 
function is carried out in the presence of deficit of one of the ions-sodium, chloride or potassium. The biological equilibrium may be initiated either by a primary change in serum bicarbonate or muscle potassium and is the same in normal and adrenalectomized rats.

The equilibrium must be regarded as biological rather than chemical because of the relatively long time required to reach the relationships. After an interval of four hours, Hastings and Eichelberger (12) found increase in cell water, but did not measure intracellular base in their experiments on alkalosis. Yannet (13) did not find shifts of electrolyte in cats with alkalosis after an interval of about 24 hours. Flexner and others (14) found equal distribution of deuterium oxide and radioactive isotopes of sodium and potassium much more rapidly.

Whatever the mechanism for bringing about the effect of serum bicarbonate on the composition of cells, the relationships must be maintained and limited by the ability of the kidneys to regulate extracellular concentrations. The development of potassium deficit on a diet low in potassium can be explained by the fact that urine is never completely devoid of potassium. When potassium is lost from the cells, it is not difficult to understand that sodium replaces the lost cation. However, it is not easy to understand why this change is accompanied by high bicarbonate and low chloride in the serum. It would seem that, if the maintenance of extracellular concentrations were the chief renal function, the kidneys could maintain normal extracellular concentrations. The effect of desoxycorticosterone acetate is brought about by a change in the excretion of sodium and potassium by the kidneys and the end result is analogous to the effect of diets low in potassium. When high serum bicarbonate was produced by deficit of chloride, it is clear that extracellular concentrations and volumes cannot both be restored without replacement of chloride, but it is not easy to explain why these changes in extracellular concentrations lead to loss of potassium and retention of sodium in the cells. Since cell membranes are considered permeable to sodium and potassium, high bicarbonate in serum must either facilitate the transfer of potassium out of the cells or increase the entrance of sodium. The other possible explanation would be that alkalosis increases the rate of potassium excretion. This explanation is unlikely, since the change in the cells takes place in the presence of abundant potassium in the diet. We are forced to conclude that the three variables are dependent and tend to adjust one to another so as to preserve the relationships exhibited in the regression equations and Figures 1 and 2.

There is considerable evidence that this biological equilibrium is exhibited by patients. In the cases of Cushing's syndrome with high serum bicarbonate, low chloride and low potassium (15, 16), the alkalosis responded to potassium chloride but not sodium chloride or ammonium chloride. Power and Kepler (17) found low potassium and high sodium in muscle taken at biopsy from one of these cases. Furthermore, the analogy with the effects of desoxycorticosterone acetate is supported by the fact that the alkalosis disappeared when an adrenal cortical tumor was removed and recurred when metastatic growths developed. The present data provide an explanation of the persistent alkalosis in cases of Cushing's syndrome-developing deficit of potassium.

Observations have shown that the alkalosis of vomiting is sometimes accompanied by low concentration of potassium in serum (18). One of the authors has observed one case of gastric tetany which persisted despite administration of abundant amounts of physiological saline. $\mathrm{He}$ also has observed a balance of sodium, potassium and chloride during recovery from dehydration following vomiting that indicated the presence of a large amount of intracellular sodium and a deficit of potassium. If these evidences of changes in cell composition in gastric alkalosis can be confirmed, gastric alkalosis must be considered to lead to deficit of potassium and excessive retention of sodium in the cells, and treatment of these disturbances with potassium chloride as well as sodium chloride is likely to prove as advantageous as the introduction of potassium chloride in the treatment of diarrhea $(19,20)$.

The observation of persistent high serum bicarbonate in certain lung diseases is also probably accompanied by the characteristic changes in the cells. Darrow and Sarason found high intracellular sodium and low potassium in rats subjected to low atmospheric pressure for seven days (21). Although the authors did not attribute the change in 
muscle composition to alkalosis, nor measure the serum bicarbonate, it is likely that compensated respiratory alkalosis explains the change.

The first evidence of the dependence of tissue composition on serum bicarbonate was recognized in a case of "congenital alkalosis with diarrhea" (22). In this patient the stools were always voluminous and watery and contained more chloride than sodium. As the boy developed more alkalosis, potassium in excess of nitrogen was lost in the stools or urine, and sodium was retained in the cells. During recovery from profound alkalosis, administration of potassium chloride facilitated partial restoration of serum bicarbonate; the retentions of electrolyte indicated that large amounts of sodium left the cells as potassium was retained, but potassium and sodium chloride were unable entirely to overcome the alkalosis. The author felt that the excessive loss of chloride in the stools was the fundamental difficulty. In studying a similar case, Gamble and others (23) postulated that there might be a fundamental difficulty in which the body adjusted preferentially to alkalosis. The present study makes this hypothesis tenable, if one could prove that the muscles and perhaps all tissues preferentially contained excessive amounts of intracellular sodium. Such a disturbance in intracellular composition is more difficult for one of the authors to visualize than a peculiar defect in intestinal absorption leading to alkalosis. In any case, the demonstration of the dependent relationship between alkalosis and muscle composition explains the excretion of potassium in the urine despite a deficit of muscle potassium. It also explains the therapeutic failure of acid salts and the refractoriness of the cases to all forms of treatment.

It must be kept in mind that the relationships under discussion may be expected to be found only when renal function has made the appropriate adjustment. Thus, we know that there are variations in one or more of the variables without the predicted changes in the others, when there is dehydration. One may be permitted to call these types of disorders unstable states with respect to the relationship between the composition of intracellular and extracellular fluids. For instance, the studies on diarrhea (19) show that this type of acidosis and dehydration is practically always accompanied by a considerable deficit of potassium, but intracellular sodium may be low or high. The regression equations predict high muscle potassium and low intracellular sodium in acidosis. The low intracellular sodium is contrary to the expectation of high intracellular sodium accompanying loss of muscle potassium. The high intracellular sodium is predicted by the potassium loss, but is contrary to the prediction from low serum bicarbonate. Diabetic coma $(24,25,26)$ probably shows similar changes in the cells accompanying acidosis and in this sense also exhibits an unstable state in the relationship between extracellular fluids and tissue composition.

One may speculate that the lack of a relatively stable equilibrium in these usually dependent variables explains some of the findings in these cases. It is obvious that deficit of potassium explains the large doses of sodium bicarbonate necessary to overcome acidosis if sodium chloride and sodium bicarbonate are administered without potassium. It is not so clear how acidosis and dehydration rapidly become manifest in some cases. The authors have in mind babies with diarrhea who suddenly manifest marked symptoms of acidosis. and dehydration despite no increase in watery stools. In these cases, if deficit of potassium develops gradually and intracellular sodium remains low or normal, an unstable state develops. Under these circumstances, acidosis and dehydration of extracellular fluids could suddenly be aggravated if sodium were rapidly transferred to the cells in consequence of the unstable state. If the transfer of sodium is equivalent to 5 per cent of the intracellular potassium, the decrease in extracellular sodium would be equivalent to one-half of the normal extracellular bicarbonate or one-tenth of the normal extracellular sodium. Since the extracellular fluids are already depleted in a patient with diarrhea, a very small shift in sodium would produce a marked aggravation of extracellular dehydration and acidosis.

On the other hand, the relationship of muscle composition to serum bicarbonate must be considered in treating disturbances in body electrolyte from the point of view of the ultimate equilibrium dependent on the tissue deficit. In diarrhea and probably also in diabetic coma $(24,25,26)$, if restoration of serum bicarbonate becomes the chief criterion of successful treatment, biological equilibrium will not be obtained with a normal serum 
bicarbonate, but with a high serum bicarbonate if deficit of potassium is not restored. For instance, a rat with a muscle potassium of $30 \mathrm{mM}$ per 100 grams of fat-free solids (about two-thirds of normal figure) is in a biological state of equilibrium when serum bicarbonate is $40 \mathrm{mM}$ per liter and intracellular sodium is $14 \mathrm{mM}$ per 100 grams of fat-free solids. If a baby behaves like a rat in this respect, the sodium in the muscle cells would be about $14 \mathrm{mM}$ per kilogram of body weight. This amount of intracellular sodium would be about three times the normal value and would be equivalent to over twice the normal amount of bicarbonate in extracellular fluids. Looking at the state of equilibrium from the point of view of the serum, profound alkalosis would be produced if administration of sodium chloride and sodium bicarbonate were forced until the kidneys reached biological equilibrium in the presence of potassium deficit. Alkalotic tetany is, therefore, not the result of a failure of renal function when there is deficit of muscle potassium, but alkalosis may be anticipated as the actual result which the kidneys tend to maintain. Since alkalosis often leads to low serum calcium, high concentration of serum bicarbonate may precipitate low calcium tetany.

Some such course of events probably explains the high incidence of tetany reported by Rapoport and others (27) in babies treated by prolonged intravenous therapy with solutions of glucose, sodium chloride and sodium bicarbonate. Since administration of calcium chloride would be effective in low calcium tetany and would tend to produce acidosis, the favorable effects of calcium salts when used in conjunction with sodium chloride and sodium bicarbonate are readily explained (27, 28). In contrast to their results, however, the authors have seldom observed low calcium tetany and have not encountered alkalosis when using potassium chloride as well as sodium chloride and sodium bicarbonate in treating infantile diarrhea.

The relationship of serum concentrations to muscle composition are also relevant to the practice of using the concentration of chloride in serum as an index of therapy. If deficit of potassium is present, serum chloride tends to be low at biological equilibrium. Administration of sodium chloride will not overcome the abnormality in serum and will probably aggravate the deficit of potassium in the muscles. In the treatment of Ad- dison's disease with desoxycorticosterone acetate, low serum chloride may indicate that too large rather than too small a dose of the drug is being used.

As in previous studies on rats, the serum potassium bears no precise relation to muscle potassium. In part, this finding may be dependent on changes in the level of serum potassium accompanying anesthesia. However, high serum potassium has been the rule when treatment is begun in patients suffering from dehydration due to diarrhea (19) and in diabetic coma (26). Robinson (29) and Larguia and Vidal (30) found that the concentration of potassium was frequently low in babies with intestinal intoxication. During treatment, the potassium concentration often reached extremely low values and if there was no tendency to return to normal, such patients died (29). Although many conditions accompanied by deficit of body potassium show low serum potassium, the exceptions are so many that the level of serum potassium cannot be relied upon as an index of the state of intracellular potassium. Nevertheless, the authors do not believe the potassium concentrations of this study should be accepted without reservations, since rats are unsuitable animals for demonstrating the relation of the concentration of potassium in serum to muscle composition owing to the difficulty in obtaining blood under resting conditions. Clinical studies must be made to evaluate the value of serum potassium as an index of deficit of potassium in tissues in various conditions.

\section{SUMMARY}

The composition of serum and muscle was determined in normal and adrenalectomized rats subjected to conditions leading to adjustment of body electrolyte in the presence of a deficit of one of the ions-sodium, chloride or potassium. Deficit of potassium was maintained by a diet low in potassium or injections of desoxycorticosterone acetate. Deficit of sodium was produced by injecting $\mathrm{NH}_{4} \mathrm{Cl}$ in glucose into the peritoneal cavity and withdrawing the fluid, and maintaining the rats on a diet deficient in sodium. Deficit of chloride was produced by injecting a solution of $\mathrm{NaHCO}_{3}$ in glucose into the peritoneal cavity and withdrawing the fluid, and maintaining the rats on a diet deficient in chloride. 
The data demonstrate a high degree of correlation between the concentration of bicarbonate in serum, muscle potassium and intracellular sodium. Thus, serum bicarbonate varies directly with intracellular sodium and inversely with muscle potassium. Muscle potassium and intracellular sodium show inverse relationships. These relationships may be considered a biological equilibrium which is attained when renal adjustment is made in the presence of a deficit of sodium or chloride or potassium.

Adrenalectomized rats show the same relationships as normal rats.

The therapeutic implications of these findings are briefly discussed. First, the relationship is known not to be maintained in dehydration and in such states we may term the lack of relationship an unstable state with respect to the relationship between extracellular and intracellular fluids. Second, patients with dehydration accompanied by deficit of potassium may be expected to develop alkalosis when they are treated solely with sodium and chloride. Third, alkalosis may be expected to be relatively refractory to treatment with sodium chloride, if a deficit of potassium persists. Fourth, the dose of sodium bicarbonate necessary to overcome low serum bicarbonate is always uncertain, since sodium may enter or leave the cells depending on the presence or absence of an excess of intracellular sodium and the presence or absence of a deficit of potassium.

\section{BIBLIOGRAPHY}

1. Darrow, D. C., Medical progress: body-fluid physiology: the relation of tissue composition to problems of water and electrolyte balance. New England J. Med., 1945, 233, 91.

2. Schwartz, R., Electrolyte studies of metabolic acidosis in the rat. Thesis submitted to the Faculty of the Yale University School of Medicine, 1947.

3. Darrow, D. C., Changes in muscle composition in alkalosis. J. Clin. Invest., 1946, 25, 324.

4. Yannet, H., and Darrow, D. C., The effect of depletion of extracellular electrolytes on chemical composition of skeletal muscle, liver and cardiac muscle. J. Biol. Chem., 1940, 134, 721.

5. Miller, H. C., and Darrow, D. C., Relation of muscle electrolyte to alterations in serum potassium and to the toxic effects of injected potassium chloride. Am. J. Physiol., 1940, 130, 747.

6. Harrison, H. E., and Darrow, D. C., The distribution of body water and electrolytes in adrenal insufficiency. J. Clin. Invest., 1938, 17, 77.
7. Miller, H. C., and Darrow, D. C., The relation of serum and muscle electrolyte, particularly potassium, to voluntary exercise. Am. J. Physiol., 1941, 132, 801.

8. Darrow, D. C., and Miller, H. C., The production of cardiac lesions by repeated injections of desoxycorticosterone acetate. J. Clin. Invest., 1942, 21, 601.

9. Ferrebee, J. W., Parker, D., Carnes, W. H., Gerity, M. K., Atchley, D. W., and Loeb, R. F., Certain effects of desoxycorticosterone: development of "diabetes insipidus" and replacement of muscle potassium by sodium in normal dogs. Am. J. Physiol., 1941, 135, 230.

10. Elkinton, J. R., Winkler, A. W., and Danowski, T. S, Inactive cell base and measurement of changes in cell water. Yale J. Biol. \& Med., 1944, 17, 383.

11. Knowlton, A. I., Loeb, E. N., Stoerk, H. C., and Seegal, B. C., Desoxycorticosterone acetate. The potentiation of its activity by sodium chloride. J. Exper. Med., 1947, 85, 187.

12. Hastings, A. B., and Eichelberger, L., The exchange of salt and water between muscle and blood. I. The effect of increase in total body water produced by the intravenous injection of isotonic salt solutions. J. Biol. Chem., 1937, 117, 73.

13. Yannet, $H$., The effect of alkalosis on the chemical composition of brain, skeletal muscle, liver and heart. J. Biol. Chem., 1940, 136, 265.

14. Flexner, L. B., Gellhorn, A., and Merrell, M., Studies on the rates of exchange of substances between blood and extravascular fluid. I. The exchange of water in the guinea pig. J. Biol. Chem., 1942, $144,35$.

15. McQuarrie, I., Johnson, R. M., and Ziegler, M. R., Plasma electrolyte disturbance in a patient with hypercorticoadrenal syndrome contrasted with that found in Addison's disease. Endocrinology, 1937, 21, 762.

16. Willson, D. M., Power, M. H., and Kepler, E. J., Alkalosis and low plasma potassium in case of Cushing's syndrome: metabolic study. J. Clin. Invest., 1940, 19, 701.

17. Power, M. H., and Kepler, E. J., Personal communication.

18. Allott, E. N., and McArdle, B., Further observations on familial periodic paralysis. Clin. Sc., 1938, 3, 229.

19. Darrow, D. C., The retention of electrolyte during recovery from severe dehydration due to diarrhea. J. Pediat., 1946, 28, 515.

20. Govan, C. D., Jr., and Darrow, D. C., The use of potassium chloride in the treatment of dehydration of diarrhea in infants. J. Pediat., 1946, 28, 541.

21. Darrow, D. C., and Sarason, E. L., Some effects of low atmospheric pressure on rats. J. Clin. Invest., 1944, 23, 11.

22. Darrow, D. C., Congenital alkalosis with diarrhea. J. Pediat., 1945, 26, 519. 
23. Gamble, J. L., Fahey, K. R., Appleton, J., and MacLachlan, E., Congenital alkalosis with diarrhea. J. Pediat., 1945, 26, 509.

24. Atchley, D. W., Loeb, R. F., Richards, D. W., Jr., Benedict, E. M., and Driscoll, M. E., On diabetic acidosis. A detailed study of electrolyte balances following withdrawal and reestablishment of insulin therapy. J. Clin. Invest., 1933, 12, 297.

25. Holler, J. W., Potassium deficiency occurring during treatment of diabetic acidosis. J. A. M. A., 1946, 131, 1186.

26. Martin, H. E., and Wertman, M., Serum potassium, magnesium and calcium levels in diabetic acidosis. J. Clin. Invest., 1947, 26, 217.
27. Rapoport, S., Dodd, K., Clark, M., and Syllm, I., Postacidotic state in infantile diarrhea: symptoms and chemical data. Postacidotic hypocalcemia and associated decreases in levels of potassium phosphorus and phosphatase in plasma. Am. J. Dis. Children, 1947, 73, 391.

28. Minot, A. S., and Dodd, K., The correction of distorted fluid equilibrium in the presence of vascular injury. J. Pediat., 1940, 17, 571.

29. Robinson, P., . Potassium in acute gastro-enteritis. Ann. Pediat., 1939, 153, 157.

30. Larguia, A. E., and Vidal, J. D., Desmineralizacion e hipopotasemia. Medicina, Buenos Aires, 1945, 5, 240.

\section{ASSOCIATION ANNOUNCEMENT}

The 40th annual meeting of the American Society for Clinical Investigation will be held at the Chalfonte-Haddon Hall, Atlantic City, N. J., on Monday, May 3, 1948, at 9 a.m.

For those who may be interested, the annual meeting of the American Association for Research in Psychosomatic Problems will be held at the same hotel on Saturday, May 1, at 9 a.m., and

The annual meeting of the Association of American Physicians will be held on Tuesday and Wednesday, May 4 and 5, also at the Chalfonte-Haddon Hall. 